\title{
Evaluation of cholesteryl ester transfer in the seminiferous tubule cells of immature rats in vivo and in vitro
}

\author{
M. Fofana, C. Travert, S. Carreau and D. Le Goff* \\ Laboratoire de Biochimie, Université de Caen, F-14032 Caen, France
}

\begin{abstract}
Sertoli cells and germ cells are separated from the interstitial blood capillaries by an extracellular matrix and the peritubular cells, which constitute a barrier to the movement of plasma lipoproteins. The present study was undertaken to evaluate in vivo and in vitro the high density lipoprotein (HDL) cholesteryl ester transfer from plasma to seminiferous tubule cells in the testis of 30-day-old rats. Firstly, the transfer of HDL cholesteryl oleate from plasma to testicular compartments was evaluated and, secondly, the role of apolipoproteins A-I and E in the uptake of cholesteryl ester by Sertoli cells was investigated. At $2 \mathrm{~h}$ after the administration of HDL reconstituted with $\left[{ }^{3} \mathrm{H}\right]$ cholesteryl ester, dimyristoyl phosphatidylcholine and apolipoproteins, the tissue space in the interstitial cells (740 $\pm 60 \mu \mathrm{lg}^{-1}$ cell protein) was fourfold higher than that in the seminiferous tubule cells $\left(170 \pm 10 \mu \mathrm{g} \mathrm{g}^{-1}\right)$. Sertoli cells were isolated and incubated with $\left[{ }^{3} \mathrm{H}\right]$ cholesteryl ester HDL reconstituted with apolipoprotein A-I or E to evaluate the mechanisms of cholesteryl ester influx. At the same apolipoprotein concentration $\left(50 \mu \mathrm{g}\right.$ apolipoprotein $\mathrm{ml}^{-1}$ medium), the uptake of $\left[{ }^{3} \mathrm{H}\right]$ cholesteryl oleate from phospholipid-apolipoprotein E vesicles was twofold higher than that with phospholipid-apolipoprotein A-I vesicles. The presence of heparin reduced the uptake of cholesteryl ester from apolipoprotein E vesicles but not with apolipoprotein A-I vesicles, indicating that uptake of apolipoprotein A-I vesicles via a secretion of apolipoprotein $\mathrm{E}$ by the cells themselves was not involved. These results demonstrate that plasma lipoprotein cholesterol is able to cross the testis lamina propria and that Sertoli cells take up cholesteryl ester for seminiferous tubule cell metabolism mainly via an apolipoprotein E pathway.
\end{abstract}

\section{Introduction}

The transport of hydrophobic constituents from plasma to interstitial cells is currently attributed to albumin and lipoproteins. Lipoproteins play a major role in the transport of cholesterol, glycerol esters, vitamins, steroid esters (Lavallée et al., 1996), lipophilic xenobiotics such as carcinogens (Polyakov et al., 1996) and drugs (Rifai et al., 1996). Low density lipoproteins (LDL) via the apolipoprotein $B-E$ receptor and high density lipoproteins (HDL) via the class B type I scavenger receptor (SR-BI) deliver cholesterol to peripheral tissues for membrane renewal and steroid hormone production (Schreiber et al., 1982; Acton et al., 1996). The relative contribution of lipoprotein cholesterol to steroid production varies according to steroidogenic cells. In adrenocortical cells, a system of fenestrated capillaries allows the easy passage of LDL and HDL and the high expression of SR-BI receptors supports the hypothesis that plasma lipoprotein is the preferential source of cholesterol for steroidogenesis (Landschulz et al., 1996; Temel et al., 1997; Azhar et al., 1998).

${ }^{*}$ Correspondence.

Received 24 March 1999
In the testis, the capillary wall constitutes the first barrier for the transfer of plasma lipoproteins to the interstitium and the Leydig cells. Testicular capillaries are characterized by a continuous layer of endothelial cells, which are connected by tight junctions (Mayerhofer et al., 1989). A system of plasmalemmal vesicles allows the passage of LDL and HDL to the interstitial compartment. Sertoli cells and germ cells are separated from the interstitial blood capillaries by an extracellular matrix and the peritubular cells, which constitute the lamina propria. Serum albumin administered to rats penetrates the lamina propria and accumulates in the Sertoli cells (Everett and Simmons, 1958; Christensen et al., 1985). The transport of lipoprotein constituents from plasma to seminiferous tubule cells has not been demonstrated. In the ovary, which presents a similar basal membrane, the blood-follicle barrier behaves like a molecular sieve which allows the passage of HDL in inverse proportion to the molecular mass (Le Goff, 1994). Therefore, the ability of lipoproteins to penetrate the testis lamina propria should be similar.

Sertoli cells extend from the basement membrane to the tubular lumen. Tight junctions exclude the diffusion of HDL from interstitial medium to the germ cells and transfer of 
hydrophobic constituents such as cholesteryl ester involves an endocytic pathway through the Sertoli cell membrane. The aim of the present study was to investigate: (i) the in vivo transfer of HDL cholesteryl ester from plasma to testicular compartments in 30-day-old rats; and (ii) the role of apolipoproteins A-I and E in the uptake of cholesteryl ester by Sertoli cells.

\section{Materials and Methods}

\section{Materials}

Dulbecco's modified Eagle's medium (DMEM) and trypsin (USP grade) were from Gibco (Cergy Pontoise); collagenase dispase was from Boehringer-Mannheim (Meylan). Soybean trypsin inhibitor, bovine pancreas deoxyribonuclease (DNAse), hyaluronidase (type I-S), dimyristoyl L- $\alpha$ phosphatidylcholine and cholesteryl myristate were from Sigma (Saint-Quentin Fallavier). Centrisart I with $20 \mathrm{kDa}$ cut-off ultrafilter was from Sartorius (Palaiseau). $(1 \alpha, 2 \alpha(n)-$ $\left.{ }^{3} \mathrm{H}\right)$ cholesteryl oleate $\left(1.78 \mathrm{TBq} \mathrm{mmol}^{-1}\right)$ was from Amersham (Les Ulis) and all other reagents were of analytical grade.

\section{$\left[{ }^{3} \mathrm{H}\right]$ cholesteryl ester reconstituted $\mathrm{HDL}$}

Labelled reconstituted HDLs were obtained after incubation of total HDL apolipoproteins (in vivo experiments) or purified apolipoproteins A-I or E (in vitro experiments) with dimyristoyl L- $\alpha$-phosphatidylcholine, cholesteryl myristate and $\left[{ }^{3} \mathrm{H}\right]$ cholesteryl oleate. Briefly, HDL (density range 1.074-1.155 $\mathrm{g} \mathrm{ml}^{-1}$ ) from pooled rat sera were isolated by sequential ultracentrifugation (Havel et al., 1955), dialysed against $1 \mathrm{mmol}$ ammonium carbonate $\mathrm{1}^{-1}$, lyophilized and lipids were removed according to the procedure of Brown et al. (1969). HDL apolipoproteins were subjected to chromatography on a heparin affinity column (heparin ultrogel A4R) as described by Dyer and Curtiss (1988). Apolipoprotein E was again purified on a heparin affinity column. Apolipoprotein A-I was then purified on Superose 12HR (Pharmacia, Orsay). Reconstituted HDL were prepared by a modification of the sodium cholate dialysis method (Zorich et al., 1987). Aliquots of dimyristoyl L- $\alpha$-phosphatidylcholine, cholesteryl myristate and $\left[{ }^{3} \mathrm{H}\right]$ cholesteryl oleate were placed in glass tubes and dried under nitrogen. Apolipoproteins were dissolved in $20 \mathrm{mmol}$ Tris- $\mathrm{HCl} \mathrm{l}{ }^{-1}, 150 \mathrm{mmol} \mathrm{NaCl} \mathrm{l}^{-1}, 0.01 \%$ (w/v) sodium azide, $0.02 \%(\mathrm{w} / \mathrm{v})$ EDTA, $\mathrm{pH} 7.4$, and added to the dried lipids. Each reaction mixture contained dimyristoyl L$\alpha$-phosphatidylcholine:cholesterol:apolipoprotein (100:10:1 molar ratios). Sodium cholate was added and the mixture was shaken overnight. Reconstituted HDL were isolated by the density gradient ultracentrifugation procedure (density range 1.074-1.155 $\mathrm{g} \mathrm{ml}^{-1}$ ) according to Chapman et al. (1981), dialysed extensively against a solution containing $150 \mathrm{mmol}$ $\mathrm{NaCl}^{-1}$, pH 7.4, concentrated with Centrisart I and sterilized through a $0.45 \mu \mathrm{m}$ micropore filter. Stereological analysis of lipoprotein particles was performed by means of a Leitz-Tas automatic image analysis system as described by Le Goff et al. (1990). On electron photomicrographs, reconstituted HDL removed from the density gradient were found to have a spherical structure with an average diameter of $12 \pm 2 \mathrm{~nm}$. The size range of particles was highly homogeneous; however, a small number of particles with a discoidal structure were detected.

\section{Determination of cholesterol transfer in vivo}

A total of 27 male Sprague-Dawley rats aged of 20-30 days were obtained from our colony. Rats were anaesthetized with sodium pentobarbital. Labelled reconstituted HDL were injected through the femoral vein. After $2 \mathrm{~h}$, the rats were killed, exsanguinated and the testes were removed. Interstitial cells, peritubular cells and Sertoli-germ cell enriched aggregates were isolated by sequential enzymatic digestions at $32^{\circ} \mathrm{C}$ as described by Tung et al. (1984). Briefly, the capsules were removed from the testes and they were treated with trypsin $\left(1.0 \mathrm{mg} \mathrm{ml}^{-1}\right)$ and DNAse $\left(0.02 \mathrm{mg} \mathrm{ml}^{-1}\right)$ in DMEM for $20 \mathrm{~min}$ at $32^{\circ} \mathrm{C}$. After addition of $0.1 \mathrm{mg}$ soybean trypsin inhibitor $\mathrm{ml}^{-1}$, interstitial cells were recovered by unit gravity sedimentation. The remaining seminiferous tubules were washed twice, subjected to enzymatic digestion using a mixture of collagenase dispase $\left(0.5 \mathrm{mg} \mathrm{ml}^{-1}\right)$ and testicular hyaluronidase $\left(1 \mathrm{mg} \mathrm{ml}^{-1}\right)$, and the peritubular cells and Sertoli-germ cell aggregates were collected by unit gravity sedimentation. The protein content of samples was determined by the bicinchoninic acid procedure (Smith et al., 1985). Cell lipids were extracted by the procedure of Hara and Radin (1978). Lipids were separated by thin layer chromatography and $\left[{ }^{3} \mathrm{H}\right]$ cholesterol spots were counted. The tissue space was expressed in terms of the plasma volume that would contain the same amount of radiolabelled compounds (Koelz et al., 1982). The tissue space was calculated as follows: (d.p.m. of cell $\left[{ }^{3} \mathrm{H}\right]$ cholesterol $\mathrm{g}^{-1}$ cell protein $) \times(\mu \mathrm{l}$ plasma per d.p.m. of plasma $\left[{ }^{3} \mathrm{H}\right]$ cholesterol); values are expressed as $\mu \mathrm{l}$ plasma $\mathrm{g}^{-1}$ cell protein. Data from these experiments are presented as the equivalent plasma space attained by cholesterol in each type of cell after $2 \mathrm{~h}$. The evaluation of cholesterol transfer from plasma HDL to seminiferous tubule cells was calculated as the ratio of seminiferous tubule cell d.p.m. to the mean of plasma HDL specific radioactivity.

\section{Sertoli cell culture}

Sertoli cells were obtained from the testes of 40 rats (20 days old, Sprague-Dawley) by sequential enzymatic digestions at $32^{\circ} \mathrm{C}$ as described by Maboundou et al. (1995). Approximately 250000 cells $\mathrm{cm}^{-2}$ were plated onto $25 \mathrm{~cm}^{2}$ plastic flasks to obtain confluent cultures. Cells were maintained in a humidified atmosphere containing 3\% $\mathrm{CO}_{2}$ at $32^{\circ} \mathrm{C}$. After $48 \mathrm{~h}$, the culture medium was replaced with fresh medium without ultroser SF (steroid-free serum substitute). On day 3, germ cells were removed by hypotonic treatment as described by Galdieri et al. (1981). 


\section{Determination of cholesterol influx}

On day 4, confluent monolayers were incubated with $\left[{ }^{3} \mathrm{H}\right]$ cholesteryl ester reconstituted HDL for $4 \mathrm{~h}$ at $32^{\circ} \mathrm{C}$ in the presence or absence of $5 \mathrm{mg}$ heparin $\mathrm{ml}^{-1}$ medium. At the end of incubation, the medium was aspirated and the cells were washed twice with cold BSA medium $\left(2.5 \mathrm{mg} \mathrm{BSA} \mathrm{m}^{-1}\right.$ cold DMEM) and once with cold PBS. Cell lipids were extracted using the procedure of Hara and Radin (1978). Cell proteins were dissolved in $0.2 \mathrm{~mol} \mathrm{NaOH} \mathrm{l}^{-1}$ (Brown et al., 1980). The protein content of samples was determined by the bicinchoninic acid procedure (Smith et al., 1985). An aliquot of the extracted lipids was counted to determine the total radioactivity incorporated into the cells. The influx was calculated as the apparent uptake of apolipoprotein and expressed as $\mu \mathrm{g}$ apolipoprotein per $\mathrm{mg}$ cell protein per $4 \mathrm{~h}$ incubation, as reported by Pittman et al. (1987).

\section{Statistical analysis}

Student's $t$ test was used to compare the effect of heparin on uptake of cholesteryl ester. Significance was assumed at $P<0.001, P<0.01$ or $P<0.05$.

\section{Results}

\section{Distribution of labelled cholesterol}

The plasma decay of radioactivity after administration of $\left[{ }^{3} \mathrm{H}\right]$ cholesteryl ester reconstituted HDL is shown (Fig. 1). A high proportion of the labelled HDL remained within the plasma: $81 \pm 3 \%$ and $66 \pm 5 \%$ at 1 and $2 \mathrm{~h}$ after injection, respectively.

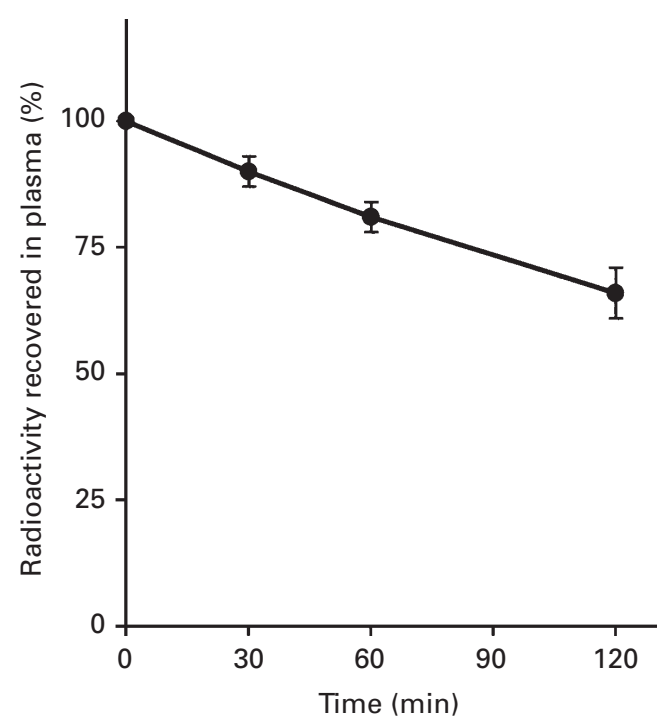

Fig. 1. Plasma decay of $\left[{ }^{3} \mathrm{H}\right]$ cholesterol in 30 -day-old rats after i.v. administration of $\left[{ }^{3} \mathrm{H}\right]$ cholesteryl oleate reconstituted high density lipoprotein (HDL). The results are expressed as the percentage of radioactivity recovered in the plasma. Values are the mean \pm SD of four experiments ( $n=3$ in each experiment).
At $2 \mathrm{~h}$ after administration of $\left[{ }^{3} \mathrm{H}\right]$ cholesterol oleate reconstituted $H D L$, the tissue spaces were $740 \pm 60,150 \pm 20$ and $170 \pm 10 \mu \mathrm{g} \mathrm{g}^{-1}$ cell protein in the interstitial cells, the peritubular cells and the seminiferous tubule cells, respectively (Fig. 2). In the interstitial cells, the tissue space was fourfold higher than that in the peritubular and seminiferous tubule cells. Transfer of cholesteryl ester between plasma and seminiferous tubule cells was estimated at approximately $25 \mathrm{ng} \mathrm{mg}^{-1}$ cell protein in $2 \mathrm{~h}$.

\section{Role of apolipoproteins A-I and E in the uptake of cholesteryl ester}

Sertoli cells apparently took up appreciable amounts of cholesteryl ester from phospholipid vesicles with apolipoprotein (Table 1). Uptake of cholesteryl ester is expressed in terms of the amount of apolipoprotein $E$ that would be delivered to the cells if the uptake was via internalization of HDL particles. At the same apolipoprotein concentration (50 $\mu \mathrm{g}$ apolipoprotein $\mathrm{ml}^{-1}$ medium), the uptake of cholesteryl oleate with phospholipidapolipoprotein E vesicles was twofold higher than that with phospholipid-apolipoprotein A-I vesicles. The presence of heparin reduced the uptake of cholesteryl ester from apolipoprotein E vesicles but not apolipoprotein A-I vesicles, indicating that the uptake of apolipoprotein A-I vesicles via secretion of apolipoprotein E by the cells themselves was not involved. The cell content of $\left[{ }^{3} \mathrm{H}\right]$ cholesterol was determined after incubation with increasing concentrations of apolipoprotein E reconstituted HDL (Fig. 3). The shape of the concentration curve indicated that uptake of $\left[{ }^{3} \mathrm{H}\right]$ cholesteryl oleate from phospholipid-apolipoprotein $\mathrm{E}$ vesicles occurred through saturable processes.

\section{Discussion}

In previous studies, transfer of plasma lipoprotein cholesterol has been estimated in the whole testes without separation of the interstitial compartment from the seminiferous tubules (Bravo et al., 1994; Woollett and Spady,

Table 1. Effect of heparin on uptake by rat Sertoli cells of $\left[{ }^{3} \mathrm{H}\right]$ cholesteryl oleate from reconstituted high density lipoprotein (HDL) containing apolipoproteins A-I or E

\begin{tabular}{lcc}
\hline & $\begin{array}{c}\text { Apparent uptake of HDL } \\
(\mu g \text { apolipoprotein per mg } \\
\text { cell protein per } 4 \mathrm{~h})\end{array}$ \\
\cline { 2 - 3 } Type of vesicle & Without heparin & With heparin \\
\hline $\begin{array}{l}\text { Phospholipid-apolipoprotein A-I } \\
\text { Phospholipid-apolipoprotein E }\end{array}$ & $1.06 \pm 0.18^{\mathrm{a}}$ & $1.07 \pm 0.09^{\mathrm{c}}$ \\
\hline
\end{tabular}

Cells were incubated for $4 \mathrm{~h}$ with reconstituted HDL apolipoproteins A-I or E (50 $\mu \mathrm{g}$ apolipoprotein $\mathrm{ml}^{-1}$ medium) in the presence or absence of $5 \mathrm{mg}$ heparin $\mathrm{ml}^{-1}$. Superscripts indicate significant differences: a versus b: $P<0.001 ; b$ versus d: $P<0.05$; c versus d: not significantly different. 


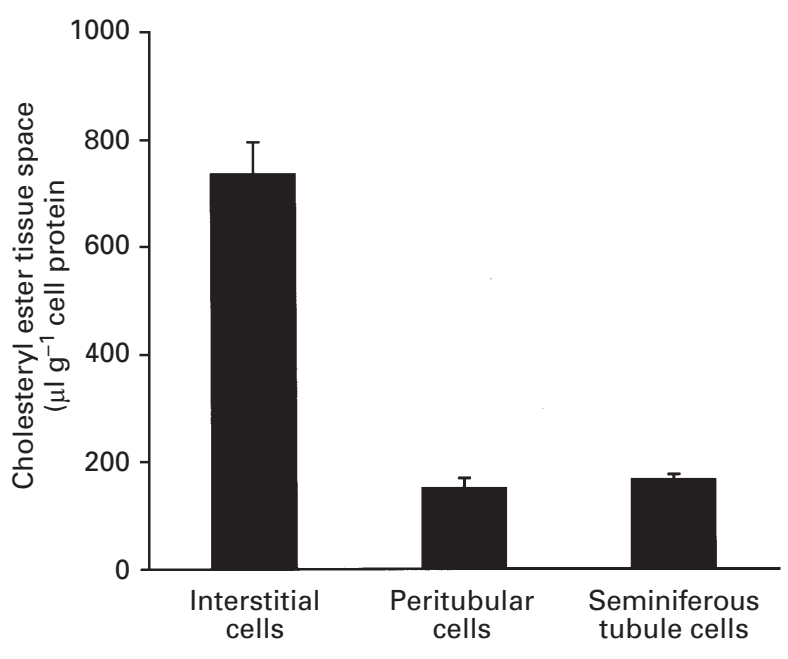

Fig. 2. Tissue space of $\left[{ }^{3} \mathrm{H}\right]$ cholesterol in rat testicular cells at $2 \mathrm{~h}$ after i.v. administration of $\left[{ }^{3} \mathrm{H}\right]$ cholesteryl oleate reconstituted high density lipoprotein (HDL). Each bar represents the mean \pm SD of five experiments ( $n=3$ in each experiment).

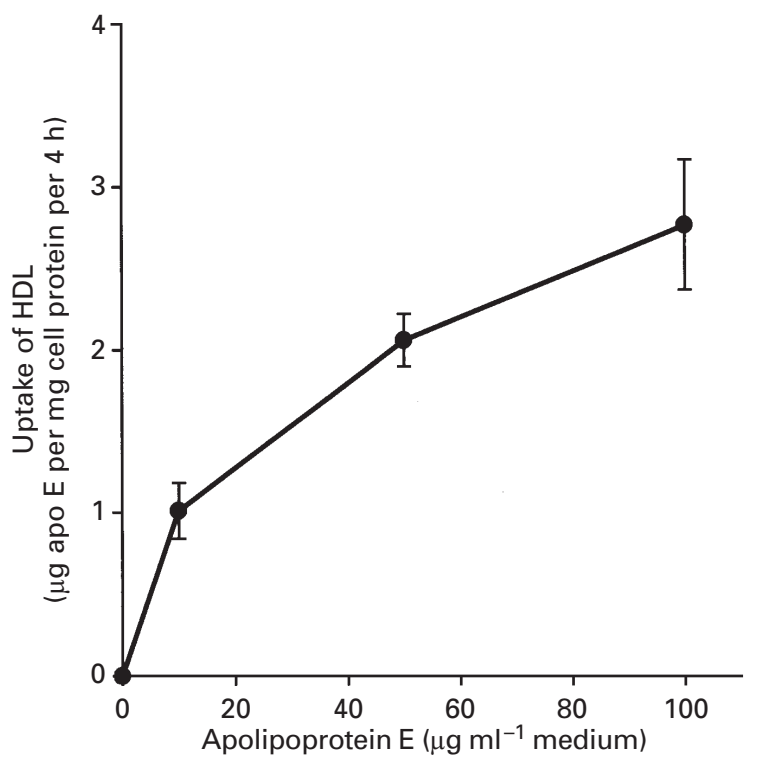

Fig. 3. Uptake of cholesteryl ester from apolipoprotein E (apo E) reconstituted high density lipoprotein (HDL) by rat Sertoli cells. Sertoli cells were obtained from the testes of 20 rats per experiment. Values are the mean \pm SD of two experiments.

1997). Everett and Simmons (1958) reported that, in rats, the transfer of ${ }^{131} \mathrm{I}$-labelled albumin from plasma into the tissue spaces begins immediately after injection and continues for many hours at different rates in various tissues. The amount of $\left[{ }^{131} \mathrm{I}\right]$ albumin in the liver and adrenal gland, which represent a system of fenestrated capillaries, was highest at 3 min after i.v. injection and decreased progressively after 30 and $60 \mathrm{~min}$. In contrast, many tissues (intestine, skin, muscle and testis) showed an increase in ${ }^{131}$ I-labelled albumin content over time. Among these tissues, the testis displayed the greatest increase at $60 \mathrm{~min}$. It has been suggested that these observed differences can be explained, at least in part, by the testicular capillaries which are characterized by a continuous layer of endothelial cells (Mayerhofer et al., 1988). In view of these observations, an incubation time of $2 \mathrm{~h}$ was used in the present study, which allows diffusion of cholesterol from plasma into the interstitial spaces and eventually into the seminiferous tubule spaces of the rat testicular tissue.

The data related to the tissue space values are the result of (i) the capacity of lipoprotein particles to cross the endothelial cells probably via the plasmalemmal vesicles; and (ii) the capacity of testicular cells to take up cholesterol through lipoprotein receptors. The results of the present study show that the cholesteryl esters pass through the sieve constituted by the extracellular matrix that is secreted by peritubular and Sertoli cells. The transfer of cholesteryl ester from plasma to the seminiferous tubule cells is fourfold lower compared with the interstitial cells and, therefore, may be involved in membrane renewal by Sertoli cells and putatively by germ cells (Levallet et al., 1998). The inability of Sertoli cells to convert cholesterol to androgens excludes the participation of exogenous cholesterol in steroid production (Gregory and Dephilip, 1998). Rat Sertoli cells can convert testosterone into oestradiol, but such steroid production requires exogenous steroid precursors and not cholesterol (Wiebe et al., 1980).

HDL are known to exchange free cholesterol between the surface of HDL and the external sheet of cell plasma membrane without internalization of cholesterol (Johnson et al., 1991). In contrast, cholesteryl ester is a poorly exchangeable fraction and its transfer into the cell requires the internalization of lipoprotein particles by the LDL receptor, LRP receptor or binding of HDL to the SR-BI receptor. The present study was conducted to determine whether Sertoli cells take up cholesteryl esters of HDL reconstituted with apolipoprotein A-I or apolipoprotein E. Rat HDL contain apolipoprotein A-I that can mediate the uptake of HDL cholesterol ester via the SR-BI receptor (Acton et al., 1996; Temel et al., 1997). In rats, adrenal cells use the HDL cholesterol rather than LDL cholesterol (Hammami et al., 1991). In addition, a significant fraction of rat HDL contains apolipoprotein $\mathrm{E}$ that can modulate the uptake of free and esterified cholesterol through internalization of HDL via the LDL receptor family. In the whole testes, significant numbers of VLDL receptors (Oka et al., 1994) and LDL receptors (Yamazaki et al., 1996) have been detected. In addition, the presence of LRP receptors has been shown by immunocytochemical analysis in Sertoli cells (Igdoura et al., 1997).

The present study demonstrated that rat Sertoli cells have the capacity to take up HDL cholesterol for cell metabolism, mainly by an apolipoprotein E pathway. In humans, HDL contain mainly apolipoprotein A-I and low concentrations of apolipoprotein E. Although SR-BI receptors are present in Sertoli cells (Shiratsuchi et al., 1999), internalization of HDL containing mainly apolipoprotein A-I could be promoted by uptake of apolipoprotein E during its passage through the testicular interstitial fluid. Leydig cells and testicular 
macrophages produce apolipoprotein E (Schleicher et al., 1993) and HDL rapidly picks up apolipoprotein E (Murdoch and Breckenridge, 1995).

In summary, the findings of the present study show that the plasma lipoprotein cholesterol is able to cross the lamina propria of the immature rat testis and that the seminiferous tubule cells take up cholesteryl ester for cell metabolism in vivo and in vitro, mainly by an apolipoprotein E pathway.

\section{References}

Acton S, Rigotti A, Landschulz KT, Xu S, Hobbs HH and Krieger M (1996) Identification of scavenger receptor SR-BI as a high density lipoprotein receptor Science $\mathbf{2 7 1}$ 518-520

Azhar S, Tsai L, Medicherla S, Chandrasekher Y, Giudice L and Reaven E (1998) Human granulosa cells use high density lipoprotein cholesterol for steroidogenesis Journal of Clinical Endocrinology and Metabolism 83 983-991

Bravo E, Botham KM, Mindham MA, Mayes PA, Marinelli T and Cantafora A (1994) Evaluation in vivo of the differential uptake and processing of high density lipoprotein unesterified cholesterol and cholesteryl ester in the rat Biochimica et Biophysica Acta 1215 93-102

Brown MS, Ho YK and Goldstein JL (1980) The cholesteryl ester cycle in macrophage foam cells. Continual hydrolysis and re-esterification of cytoplasmic cholesteryl esters Journal of Biological Chemistry 255 9344-9352

Brown WV, Levy RI and Frederickson DS (1969) Studies of the proteins in human plasma very low density lipoproteins Journal of Biological Chemistry 244 5687-5694

Chapman MJ, Goldstein S, Lagrange D and Laplaud PM (1981) A density gradient ultracentrifugal procedure for the isolation of the major lipoprotein classes from human serum Journal of Lipid Research 22 339-358

Christensen AK, Komorowski TE, Wilson B, Ma SF and Stevens RW, III (1985) The distribution of serum albumin in the rat testis, studied by electron microscope immunocytochemistry on ultrathin frozen sections Endocrinology 116 1983-1996

Dyer CA and Curtiss LK (1988) Apoprotein E-rich high density lipoproteins inhibit ovarian androgen synthesis Journal of Biological Chemistry 26310 965-10973

Everett NB and Simmons B (1958) Measurement and radioautographic localization of albumin in rat tissues after intravenous administration Circulation Research 6 307-313

Galdieri M, Ziparo E, Palombi F, Russo M and Stefanini M (1981) Pure Sertoli cells: a new model for the study of somatic germ cell interactions Journal of Andrology 5 249-254

Gregory CW and Dephilip RM (1998) Detection of steroidogenic acute regulatory protein (StAR) in mitochondria of cultured rat Sertoli cells incubated with follicle-stimulating hormone Biology of Reproduction 58 470-474

Hammami M, Meunier S, Maume G, Gambert P and Maume BF (1991) Effect of rat plasma high density lipoprotein with or without apolipoprotein $\mathrm{E}$ on the cholesterol uptake and on the induction of the corticosteroid biosynthetic pathway in newborn rat adrenocortical cell cultures Biochimica et Biophysica Acta 1094 153-160

Hara A and Radin NS (1978) Lipid extraction of tissues with a low-toxicity solvent Analytical Biochemistry $90420-426$

Havel RJ, Eder HA and Bragdon JH (1955) The distribution and chemical composition of ultracentrifugally-separated lipoproteins in human serum Journal of Clinical Investigation 58 1345-1353

Igdoura SA, Argraves WS and Morales CR (1997) Low density receptor related protein expression in the testis: regulated expression in Sertoli cells Journal of Andrology 18 400-410

Johnson WJ, Mahlberg FH, Rothblat GH and Philipps MC (1991) Cholesterol transport between cells and high-density lipoproteins Biochimica et Biophysica Acta 1085 273-298

Koelz HR, Sherrill BC, Turley SD and Dietschy JM (1982) Correlation of low and high density lipoprotein binding in vivo with rates of lipoprotein degradation in the rat Journal of Biological Chemistry 257 8061-8072

Landschulz KT, Pathak R, Rigotti A, Krieger M and Hobbs HH (1996) Regulation of scavenger receptor, class B, type I, a high density lipoprotein receptor in liver and steroidogenic tissues of the rat Journal of Clinical Investigation 98 984-995
Lavallée B, Provost PR, Roy R, Gauthier MC and Bélanger A (1996) Dehydroepiandrosterone-fatty acid esters in human plasma: formation, transport and delivery to steroid target tissues Journal of Endocrinology 150 S119-S124

Le Goff D (1994) Follicular fluid lipoproteins in the mare: evaluation of HDL transfer from plasma to follicular fluid Biochimica et Biophysica Acta $\mathbf{1 2 1 0}$ 226-232

Le Goff D, Nouvelot A and Chermant JL (1990) Determination of size and molecular weight distributions of lipoproteins using automatic image analysis and density gradient ultracentrifugation Journal of Biochemical and Biophysical Methods $20247-258$

Levallet J, Bilinska B, Mittre H, Genissel C, Fresnel J and Carreau S (1998) Expression and immunolocalization of functional cytochrome P450 aromatase in mature rat testicular cells Biology of Reproduction 58 919-926

Maboundou JC, Fofana M, Fresnel J, Bocquet J and Le Goff D (1995) Effect of lipoproteins on cholesterol synthesis in rat Sertoli cells Biochemistry and Cell Biology 73 67-72

Mayerhofer A, Hikim APS, Bartke A and Russell LD (1989) Changes in the testicular microvasculature during photoperiod-related seasonal transition from reproductive quiescence to reproductive activity in the adult golden hamster Anatomical Record 224 495-507

Murdoch SJ and Breckenridge WC (1995) Influence of lipoprotein lipase and hepatic lipase on the transformation of VLDL and HDL during lipolysis of VLDL Atherosclerosis 118 193-212

Oka K, Ishimura-Oka K, Chu MJ, Sullivan M, Krushkal J, Li WH and Chan L (1994) Mouse very low density lipoprotein receptor (VLDLR) cDNA cloning, tissue specific expression and evolutionary relationship with the low density lipoprotein receptor European Journal of Biochemistry 224 975-982

Pittman RC, Knecht TP, Rosenbaum MS and Taylor CA (1987) A nonendocytotic mechanism for the selective uptake of high density lipoprotein-associated cholesterol ester Journal of Biological Chemistry 262 2443-2450

Polyakov LM, Chasovskikh ML and Panin LE (1996) Binding and transport of benzo[a]pyrene by blood plasma lipoproteins: the possible role of apolipoprotein B in this process Bioconjugate Chemistry 7 396-400

Rifai N, Chao FF, Pham Q, Thiessen J and Soldin SJ (1996) The role of lipoproteins in the transport and uptake of cyclosporine and dihydrotacrolimus into HepG2 and Jurkat cell lines Clinical Biochemistry 29 149-155

Schleicher RL, Zheng $\mathbf{M}$ and Zhang M (1993) Immunocytochemical localization and endogenous synthesis of apolipoprotein $\mathrm{E}$ in testicular Leydig cells Biology of Reproduction 48 313-324

Schreiber JR, Weinstein DB and Hsueh AJW (1982) Lipoproteins stimulate androgen production by cultured rat testis cells Journal of Steroid Biochemistry 16 39-43

Shiratsuchi A, Kawasaki Y, Ikemoto M, Arai H and Nakanishi Y (1999) Role of class B scavenger receptor type I in phagocytosis of apoptotic rat spermatogenic cells by Sertoli cells Journal of Biological Chemistry 274 5901-5908

Smith PK, Krohn RI, Hermanson GT et al. (1985) Measurement of protein using bicinchoninic acid Analytical Biochemistry 150 76-85

Temel RE, Trigatti B, Demattos RB, Azhar S, Krieger M and Williams DL (1997) Scavenger receptor class B, type I (SR-BI) is the major route for the delivery of high density lipoprotein cholesterol to the steroidogenic pathway in cultured mouse adrenocortical cells Proceedings National Academy of Sciences USA 94 13 600-13 605

Tung PS, Skinner MK and Fritz IB (1984) Fibronectin synthesis is a marker for peritubular cell contaminants in Sertoli enriched cultures Biology of Reproduction 30 199-211

Wiebe JP, Tilbe KS and Buckingham (1980) An analysis of the metabolites of progesterone produced by isolated Sertoli cells at the onset of gametogenesis Steroids 35 561-577

Woollett LA and Spady DK (1997) Kinetic parameters for high density lipoprotein apoprotein AI and cholesteryl ester transport in the hamster Journal of Clinical Investigation 99 1704-1713

Yamazaki H, Bujo H, Kusunoki J, Seimiya K, Kanaki T, Morisaki N, Schneider WJ and Saito Y (1996) Elements of neural adhesion molecules and a yeast vacuolar protein sorting receptor are present in a novel mammalian low density lipoprotein receptor family member Journal of Biological Chemistry 27124 761-24 768

Zorich NL, Kézdy KE and Jonas A (1987) Properties of discoidal complexes of human apolipoprotein A-I with phosphatidylcholines containing various fatty acid chains Biochimica et Biophysica Acta 919 181-189 